\title{
Subclinical-Hypothyroidism: A Pathology in Evolution
}

\author{
Sikandar Hayat Khan ${ }^{1}$ and Aamir ljaz²
}

\begin{abstract}
Subclinical-hypothyroidism is identified as suboptimal thyroid hormonal production associated with mild TSH (thyroid stimulating hormone) elevation. Though several non-thyroidal illness in the later stages, medications and dietary supplements may resemble SCH (subclinical-hypothyroidism), but mild persistent subnormal thyroidal pathologies are usually termed as $\mathrm{SCH}$. This review briefly describes the various cardiovascular risk associations with subclinicalhypothyroidism and attempts to provide an insight into the risk and benefit association, which a patient faces once treated for $\mathrm{SCH}$.
\end{abstract}

Key Words: Euthyroidism, Subclinical-hypothyroidism (SCH), L-thyroxine (L-T4), Cardiovascular diseases (CVD).

\section{INTRODUCTION}

Subclinical-hypothyroidism $(\mathrm{SCH})$ is defined when TSH values are more than $4.0 \mathrm{mIU} / \mathrm{L}$ but less than $10 \mathrm{mIU} / \mathrm{L}$ with normal thyroid hormones (fT4 and fT3). ${ }^{1}$ Before we make a diagnosis of $\mathrm{SCH}$, it is important to ensure that borderline TSH rise persisted for some time and there are no conditions affecting hypothalamic-pituitary axis, medicines affecting thyroid function and over the counter medications, certain dietary supplements, and nonthyroidal illnesses (NTI). While cut-offs, methodologies, and regional differences can cause differences in TSH measurements, therefore, variance in $\mathrm{SCH}$ prevalence, literature review from NHANES III surveys and the Whickam study from UK provides a prevalence from $4.3 \%$ and $7.5 \%$ alternatively. ${ }^{2,3}$ Gender, age, physiological changes (pregnancy) and non-thyroid pathologies do affect the measured thyroid hormones. ${ }^{4}$ The entity $\mathrm{SCH}$ being commonly prevalent is also questioned as whether being an outlier in the spectrum of TSH physiology or some physiological adjustment of basal metabolic rate (BMR) or a pathology in evolution. Clinically, dilemma starts when questions are raised whether to adopt conservatism or treatment need to be started to address any thyroid complications.

The concept of thyroid well-being could be a broader and seem expanding than our current perception requiring quality data to elaborate $\mathrm{SCH}$. While the etiological aspects and patient population remain unknown in most case, the core concept encompasses an apparently asymptomatic medical condition where the focus is to

1 Department of Pathology, PNS Hafeez, Islamabad, Pakistan

2 Department of Chemical Pathology and Clinical Endocrinology, Armed Forces Institute of Pathology (AFIP), Rawalpindi,

Pakistan

Correspondence: Dr. Sikandar Hayat Khan, Department of

Pathology, PNS Hafeez, Islamabad, Pakistan

E-mail: sik_cpsp@yahoo.com

Received: April 24, 2018; Accepted: September 15, 2018 treat, monitor or not to intervene. 5 The commonest query from both the physicians and the patients is regarding the normality spectrum of TSH hormone with fears emerging from under- and over-treatment. Consequent upon the highlighted issues, the authors planned to review data to provide an insight into the $\mathrm{SCH}$ along with guidance towards possible management strategy in the light of risks and benefits.

Literature search strategy: The review was conducted from January 2015 to April 2018. Articles published in only English language or with translation into English were included in the review. We reviewed data with the key words "subclinical-hypothyroidism (SCH)" from Pakmedinet and PubMed. Commentaries, conference proceedings, letters to editors, articles without peer reviews, reports from newspapers from the PubMed group were excluded. The initial search key words "subclinical-hypothyroidism" in adults yielded 2,186 studies on PubMed. Excluding pediatric studies and limiting further to subclinical hypothyroidism and cardiovascular risks in adults provided 289 studies on PubMed. Further limitations in terms of articles published in last 10 years brought the countdown to 200 . Limiting further to randomised control trials shortened the list to 8 articles. Seven articles were finally included as they addressed in some way dealing CVD risk association in adults with $\mathrm{SCH}$. Similar search on Pakmedinet provided 24 studies with key words "subclinical-hypothyroidism" or "subclinical thyroid disease". Studies carried out in children, only in specific diseases like coeliac disease patients or not targeting CVD in any way were excluded. Only 10 studies were analysed further. All studies were observational with only one study evaluated a cohort.

\section{RESULTS}

The data from Pakmedinet was exuberant in terms of only scarcity as none of the studies were a randomised control trial or equivalent. Details of 10 studies, which suggested in anyway, the $\mathrm{SCH}$ has been mentioned in 
Table I: Local data from pakmedinet.com on subclinical-hypothyroidism and cardiovascular diseases in adults ( $\mathrm{n}=10$ ).

\begin{tabular}{|c|c|c|c|c|c|}
\hline Study & Type of study & Journal & $\mathrm{SCH}$ frequency $(\mathrm{n})$ & End point & Comments \\
\hline ljaz A et al. & $\begin{array}{l}\text { Cross-sectional } \\
\text { study }\end{array}$ & $\begin{array}{l}\text { J Coll Physicians Surg } \\
\text { Pak (Feb 2002) }\end{array}$ & $31 \%$ & $\begin{array}{l}\text { Frequency of subclinical thyroid } \\
\text { diseases }\end{array}$ & - \\
\hline Cakmak et al. & $\begin{array}{l}\text { Comparative } \\
\text { cross-sectional } \\
\text { study }\end{array}$ & $\begin{array}{l}\text { J Pak Med Assoc } \\
\text { (Oct 2011) }\end{array}$ & - & $\begin{array}{l}\text { Reduction in pulmonary } \\
\text { function tests }\end{array}$ & - \\
\hline Shafit M et al. & $\begin{array}{l}\text { Case control } \\
\text { study }\end{array}$ & $\begin{array}{l}\text { Biomedica } \\
\text { (Jan - Mar 2013) }\end{array}$ & - & $\begin{array}{l}\text { Lipid parameters in overt } \\
\text { hypothyroidism }\end{array}$ & $\begin{array}{l}\text { Worsening of lipid parameters in subjects } \\
\text { with overt disease }\end{array}$ \\
\hline Asif $\mathrm{M}$ et al. & $\begin{array}{l}\text { Cross-sectional } \\
\text { analytical study }\end{array}$ & $\begin{array}{l}\text { Professional Med J } \\
\text { (Aug 2013) }\end{array}$ & - & $\begin{array}{l}\text { eGFR as calculated by Cock- } \\
\text { croft-Gualt formula }\end{array}$ & $\begin{array}{l}\text { eGFR worsening with deterioration in } \\
\text { thyroid functioning }\end{array}$ \\
\hline Shabbir B et al. & Descriptive study & $\begin{array}{l}\text { Pak J Med Health Sci } \\
\text { (Jan - Mar 2012) }\end{array}$ & $\begin{array}{l}5 \% \text { in diabetic } \\
\text { population }(n=100)\end{array}$ & - & $\begin{array}{l}\text { Risk segregation not based upon hypo or } \\
\text { hyper thyroid disease }\end{array}$ \\
\hline Anwer SM et al. & Cohort study & $\begin{array}{l}\text { J Ayub Med } \\
\text { CollAbottabad } \\
\text { (Oct - Dec 2012) }\end{array}$ & $14 \%(n=100)$ & $\begin{array}{l}\text { Progression to overt } \\
\text { hypothyroidism }\end{array}$ & - \\
\hline Humerah S et al. & $\begin{array}{l}\text { Cross-sectional } \\
\text { study }\end{array}$ & $\begin{array}{l}\text { J Coll Physicians Surg } \\
\text { Pak (Jun 2016) }\end{array}$ & $20 \%(n=100)$ & Lipid parameters & $\begin{array}{l}\text { Worsening of lipid parameters in subjects } \\
\text { with overt disease }\end{array}$ \\
\hline Gul N et al. & $\begin{array}{l}\text { Cross sectional } \\
\text { study }\end{array}$ & $\begin{array}{l}\text { J Ayub Med Coll } \\
\text { Abottabad } \\
\text { (Apr - Jun 2016) }\end{array}$ & $9.78 \%(n=378)$ & $\begin{array}{l}\text { Frequency of SCH in hospital } \\
\text { seting }\end{array}$ & - \\
\hline Naib MJ et al. & Prospective study & J Med Sci (Oct 2014) & $\begin{array}{l}27 / 320 \text { ( } n=320 \text { sub- } \\
\text { fertile subjects) }\end{array}$ & $\begin{array}{l}\text { Subfertility in SCH group \& } \\
\text { associated thyroid disorders }\end{array}$ & $\begin{array}{l}\text { Subfertility associated with deranged } \\
\text { thyroid profile }\end{array}$ \\
\hline Ullah A. & $\begin{array}{l}\text { Descriptive cross- } \\
\text { sectional study }\end{array}$ & $\begin{array}{l}\text { Khyber Med Uni Med J } \\
\text { (Jul - Sep 2013) }\end{array}$ & $6.1 \%(n=753)$ & $\begin{array}{l}\text { Thyroid disorders in } \\
\text { Congestive heart failure }\end{array}$ & $\mathrm{SCH}$ not very common in $\mathrm{CHF}$ patients \\
\hline Ali L et al. & $\begin{array}{l}\text { Cross-sectional } \\
\text { study }\end{array}$ & $\begin{array}{l}\text { Professional Med } \mathrm{J} \\
\text { (Oct 2015) }\end{array}$ & $9 \%(n=100)$ & $\begin{array}{l}\text { Generalized risk associations } \\
\text { with all CVD disorders }\end{array}$ & $\begin{array}{l}\text { Subclinical thyroid dysfunction are at } \\
\text { increased risk of CVD }\end{array}$ \\
\hline
\end{tabular}

Table I, along with the frequency of $\mathrm{SCH}$ and associated risk factors. Pubmed review yielded seven clinical trials which evaluated post-interventional response in subjects with $\mathrm{SCH}$. Almost all these trials identified worsening of some or all lipid parameters, endothelial dysfunction, insulin resistance, increase in inflammatory markers, CVD risk and higher carotid intima media thickness (CIMT) in subjects with $\mathrm{SCH}$, which responded to clinical intervention. Details are mentioned in Table II.6-12 Figures 1 and 2 provide suggested algorithms for managing a case with $\mathrm{SCH}$.

\section{DISCUSSION}

The evolving evidence provides an insight about the hypothalamic-pituitary-thyroid axis in better ways than before, but still there are grey areas in literature which require further attention. Canaris et al. observed in "The Colorado thyroid disease prevalent study" that patients having mildly raised TSH levels had lipid abnormalities and can lead to adverse cardiovascular health issues. ${ }^{13}$ These patients with mildly elevated TSH levels, though do not present in clinics, are usually picked up on routine screening and then the physician ends up with a confusion to treat or to adopt a conservative approach. The usual in vogue clinical indication is to treat a raised TSH level beyond $10 \mathrm{mIU} / \mathrm{L}$, i.e. overt hypothyroidism. TSH levels, which are above the range of normality but below $10 \mathrm{mIU} / \mathrm{L}$ and do cause concern to both physician and patients and leads sometimes to unnecessary interventions and investigations. Furthermore, patients with anti-TPO positivity, lipidemias, or ischemic heart diseases are usually not considered as association to $\mathrm{SCH} .{ }^{14}$ Finally, there are other conditions like pregnancy, iodine deficiency, celiac disease, history of autoimmune disorders, which are also required to be excluded as they are associated with higher rate of $\mathrm{SCH}$ progression towards overt disease. ${ }^{15,16}$ Available data highlights a cautious approach highlighting both risks and benefits, which are being discussed.

Treatment with thyroxin (L-T4) once evaluated by TSH normally lags behind the clinical and biochemical response by a margin of 8-12 weeks from the baseline. The apparent concerns arise once a patient with $\mathrm{SCH}$ is started with treatment to address mild clinical or biochemical derangements overshoots normality limits to end up having treatment-associated complications along with worsening of any underlying autoimmune disease like adrenocortical deficiency. These overtreatment related concerns have been appreciated below.

Cardiovascular (CVD) risks: Overtreatment with thyroxin can lead to possible hyperthyroidism. Though mild L-T4 treatment for a short duration may not cause any harm, but treatment for a longer duration with inappropriate clinical and biochemical monitoring can lead to CVD issues including diastolic dysfunction, left 
ventricular hypertrophy, and fatal atrial arrhythmias. ${ }^{17}$ So, even minor over replacement of thyroxin must be avoided in patients to prevent adverse cardiac effects, especially so in geriatric population. ${ }^{18}$

Pregnancy: Casey et al. observed that subclinical hyperthyroidism not to be associated with non-desirable pregnancy-related outcomes. ${ }^{19}$ Alongside, we do appreciate that the upper range of TSH is suppressed $(2.5 \mathrm{mlU} / \mathrm{L})$ in first trimester, only to rise by third trimester. So keeping these differential normality ranges in mind and the data from authors like Atkins et al., highlighted legitimate maternal and fetal concerns due to hyperthyroidism associated with anti-thyroid treatments during pregnancy. 20 Therefore, caution needs to be exercised while prescribing L-T4 therapy in pregnant subjects with $\mathrm{SCH}$ till further research on the subject is available.
Sympathetic overactivity: Thyroxin stimulates adrenaline surge, thus overtreating subjects with L-T4 may lead to sympathetic overactivity. ${ }^{21}$ Studies carried out in subjects with subclinical-hyperthyroidism are characterised by increase in sympathetic activity and parasympathetic imbalances. 21

Neuromuscular effects: Overt hypothyroidism is associated with decrease in nerve conduction and muscle weakness. Moreover, subclinical-hyperthyroidism is also associated with cognitive decline.22 Brennan et al. have highlighted that strength and cross-sectional area of muscles decrease in patients with subclinicalhyperthyroidism. ${ }^{23}$

Thyroid eye disease and dermopathy: Grave's disease and thyroid dermopathy have mostly been observed with hyperthyroidism. In our opinion, such predispositions to autoimmunity may get aggravated in

Table II: Data from PubMed randomised controlled trials data on subclinical-hypothyroidism and cardiovascular diseases in adults from last

\begin{tabular}{|c|c|c|c|c|c|}
\hline Study & Subject selection & Intervention & Main end points & Comments & Conclusion \\
\hline $\begin{array}{l}\text { Herter-Aeberl I } \\
\text { et al. }{ }^{6}\end{array}$ & $\begin{array}{l}\text { lodine-deficient, } \\
\text { overweight } \\
\text { Moroccan women } \\
(n=163)\end{array}$ & $\begin{array}{l}200 \text { ug iodine or } \\
\text { placebo } \times 6 \text { mo }\end{array}$ & $\begin{array}{l}\cdot \text { TSH } \\
\cdot \text { Total chol (TC) } \\
\cdot \text { - LDLC } \\
\cdot \text { Plasma glucose }\end{array}$ & $\begin{array}{l}- \text { TSH reduction by } 33 \% \text { in } \\
\text { iodine group } \\
\text { - TC reduction by } 38 \% \text { in } \\
\text { iodine vs } 38 \% \text { in placebo } \\
\text { - LDLc reduced }(p=0.23)\end{array}$ & $\begin{array}{l}\text { lodine prophylaxis in iodine deficient } \\
\text { females reduced CVD }\end{array}$ \\
\hline $\begin{array}{l}\text { AlibazOner F } \\
\text { et al. } .^{7}\end{array}$ & $\begin{array}{l}27=\mathrm{SCH} \text { cases } \\
22=\text { Health } \\
\text { controls }\end{array}$ & LT4 therapy & $\begin{array}{l}- \text { Flow-mediated } \\
\text { diameter (FMD) as } \\
\text { marker for endothelial } \\
\text { function }\end{array}$ & $\begin{array}{l}\text { - Improvement in FMD in } \mathrm{SCH} \\
\text { cases in comparison to } \\
\text { healthy controls }\end{array}$ & $\begin{array}{l}\text { Thyroid hormone replacement therapy } \\
\text { may help to prevent atherosclerosis in this } \\
\text { group of patients. }\end{array}$ \\
\hline $\begin{array}{l}\text { Kowalska I } \\
\text { et al. } 8\end{array}$ & $\begin{array}{l}13 \mathrm{SCH} \text { females } \\
14 \text { euthyroid } \\
\text { controls }\end{array}$ & LT4 therapy & $\begin{array}{l}\text { - sICAM-1 } \\
\text { - Adiponectin } \\
\text { - Insulin sensitivity } \\
\text { - LDLC } \\
\text { - Plasma glucose }\end{array}$ & $\begin{array}{l}\text { - sICAM-1 decreases }(P=0.01) \\
\text { - Adiponectin }(N S) \\
\text { - Insulin sensitivity improved } \\
(p=0.012) \\
\text { - LDLc } \\
\text { - Plasma glucose decreased } \\
(p=0.019)\end{array}$ & $\begin{array}{l}\text { L-thyroxine treatment in patients with } \\
\text { subclinicalhypothyroidism might exert a } \\
\text { beneficial effect by reducing } \\
\text { cardiovascularrisk factors }\end{array}$ \\
\hline $\begin{array}{l}\text { Sathyapalan T } \\
\text { et al. } .^{9}\end{array}$ & $\begin{array}{l}60 \mathrm{SCH} \text { cases } \\
\text { Cross-over trial }\end{array}$ & $\begin{array}{l}\text { Western diet } \\
\text { OR } \\
\text { Vegetarian diet }\end{array}$ & $\begin{array}{l}- \text { Progression to overt } \\
\text { hypothyroidism } \\
\text { - Blood pressure } \\
\text { - Insulin resistance } \\
\text { - Lipids } \\
\text { - hsCRP }\end{array}$ & $\begin{array}{l}\text { Vegetarian diets caused: } \\
\text { - Increased progression to } \\
\text { overt hypothyroidism } \\
\text { phytoestrogens } \\
\text { - Blood pressure decreased } \\
\text { - HOMA-IR }[3.5 \pm 0.09 \text { vs. } 2.6 \\
\pm 0.08 ; p<0.02] \\
\text { - Lipids (NS) } \\
\text { - HsCRP }(4.9 \pm 0.04 \text { vs. } 3.9 \\
\pm 0.03 ; p<0.01)\end{array}$ & $\begin{array}{l}\text { Vegetarian diets increased progression to } \\
\text { Overt hypothyroidism }\end{array}$ \\
\hline $\begin{array}{l}\text { Shakoor SK } \\
\text { et al. } 10\end{array}$ & $\begin{array}{l}\mathrm{SCH}=20 \\
\text { Control }=20\end{array}$ & LT4 therapy & $\begin{array}{l}\text { Endothelial progenitor } \\
\text { cells }(E P C), \\
\text { representing CV risk } \\
\text { as: } \\
\cdot \text { EPC count } \\
- \text { EPC function }\end{array}$ & $\begin{array}{l}\text { - EPC count increased } \\
\text { - EPC function improved }\end{array}$ & $\begin{array}{l}\text { LT4 treatment regressed progression to } \\
\text { overt hypothyroidism and reduced CVS } \\
\text { risk }\end{array}$ \\
\hline $\begin{array}{l}\text { Adrees M } \\
\text { et al. }{ }^{11}\end{array}$ & $\begin{array}{l}\mathrm{H}=56 \\
\text { Control=56 }\end{array}$ & LT4 therapy & $\begin{array}{l}\cdot \text { CIMT } \\
- \text { Carotid and brachial } \\
\text { artery } \\
\cdot \text { eGFR }\end{array}$ & $\begin{array}{l}\text { - CIMT reduce } \\
\text { - Carotid and brachial artery } \\
\text { diameter increase } \\
\text { - eGFR improves }\end{array}$ & $\begin{array}{l}\text { LT4 therapy reduce CIMT, increased } \\
\text { carotid and brachial artery diameters and } \\
\text { eGFR in subjects with SCH }\end{array}$ \\
\hline $\begin{array}{l}\text { Mikhail GS } \\
\text { et al. }{ }^{12}\end{array}$ & $\begin{array}{l}\text { LT4 treated } \\
\text { SCH }=60 \\
\text { LT4 non-treated } \\
\text { Controls }=60\end{array}$ & LT4 therapy & $\begin{array}{l}- \text { Total cholesterol } \\
\text { LDLC } \\
\text { - HDLC } \\
\text { - Triglycerides }\end{array}$ & $\begin{array}{l}\text { Improvement in lipid } \\
\text { parameter in LT4 treated vs. } \\
\text { non-treated group were as: } \\
\text { - Total cholesterol }(\mathrm{P}<0.001) \\
\text { - LDLc(p<0.01) } \\
\text { - HDLc (NS) } \\
\text { - Triglycerides (NS) }\end{array}$ & $\begin{array}{l}\text { LT4 treatment reduced LDLC and total } \\
\text { cholesterol }\end{array}$ \\
\hline
\end{tabular}


patients who are overtreated with thyroxin. However, research is needed to address this association.

Bone mineral density (BMD): Hyperthyroid subjects have decrease bone mineral density. De Rosa et al. have highlighted L-T4 overreplacement resulting in bone mineral density loss in subjects who were treated for non-toxic goitre. 24 This tendency to bone mineral density loss has also been observed by other researchers. 25
Regarding the association of hyperthyroidism with BMD, few have suggested that BMD and BMD may not decrease after thyroxin treatment. 26 Greenspan et al. compared both pre-menopausal and post-menopausal ladies for long-term effect of thyroxin on BMD by keeping thyroid parameters within their physiological range to conclude that L-T4 therapy may not be a contraindication due to possible concerns affecting skeletal

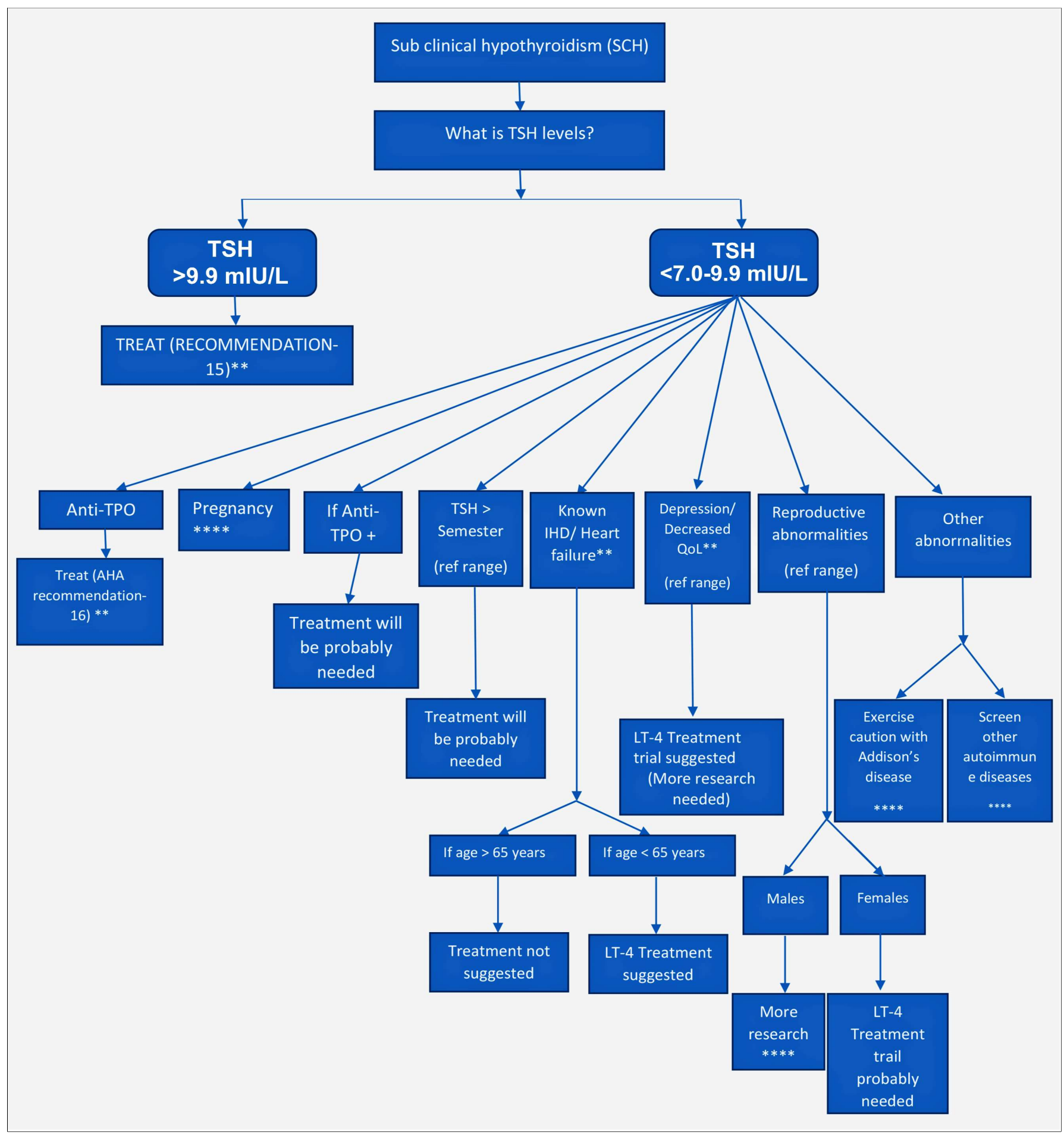

Figure 1: Suggested algorithm for management options with regard to evaluated risks and benefits in subjects having TSH levels from 4.0 to $7.0 \mathrm{ml}$ U/L. ${ }^{*}$ Confirm the SCH diagnosis by R/O the effects of drugs, NTI, and other factors. ${ }^{* *}$ ATA adult treatment guidelines. ${ }^{* \star \star}$ The Whickman survey. ${ }^{* \star \star *}$ Treatment assessment based upon combined risk assessment. 


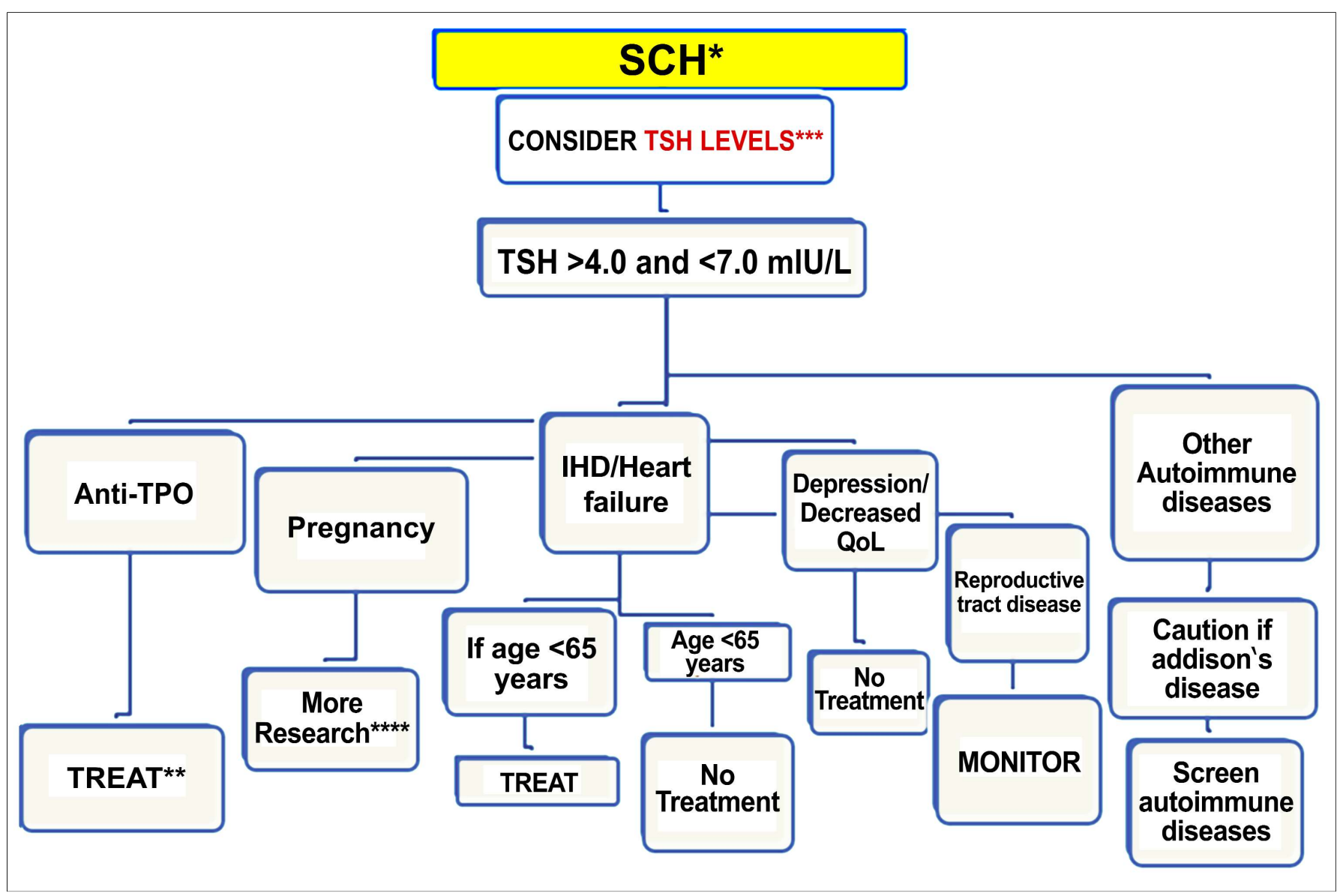

Figure 2: Suggested algorithm for management options with regard to evaluated risks and benefits in subjects with TSH $>7.0 \mathrm{ml}$ U/L.

${ }^{*}$ Confirm the SCH diagnosis by R/O the effects of drugs, NTI, and other factors. ${ }^{* \star}$ ATA adult treatment guidelines. ${ }^{* \star \star}$ The Whickman survey. ${ }^{* \star \star *}$ Treatment assessment based upon combined risk assessment.

integrity. ${ }^{27}$ In view of the aforementioned discussion and logical perspective, it may be suggested that decline in BMD can only be expected with over-dosage of thyroxin in subjects with $\mathrm{SCH}$, so treatment may be initiated, keeping TSH levels within target range.

Adrenal deficiency: Managing a patient with $\mathrm{SCH}$ or overt hypothyroidism with concomitant adrenocortical deficiency can lead to serious adverse outcomes and thus not suggested. Recent data suggest autoimmunity may cause borderline rise in TSH, especially with autoimmune disorder which may not be in singular and may be associated with polyglandular autoimmune syndrome (PGAS). Thus, SCH association with adrenocortical deficiency may also be included in differentials before initiating L-T4 therapy. ${ }^{28}$ Furthermore, evidence is also there to suggest remission of hypothyroidism once a subject is initiated treatment with steroid for adrenal deficiency. ${ }^{29,30}$ Therefore, subjects having $\mathrm{SCH}$ or overt hypothyroidism may be clinically screened for possible adreno-cortical deficiency.

Advantages: Though the side effects related with $\mathrm{SCH}$ treatment are obvious and related to initial TSH level and dosage, benefits are required to be acknowledged:

CVD benefits: The Whickham survey from United Kingdom evaluated the incidence of CVD events over a 20-year follow-up, and concluded that CVD events were higher among subjects with mildly raised TSH levels $(\mathrm{SCH}) .{ }^{31}$ Gencer et al. conducted a prospective controlled trial involving over 25,000 subjects and showed that the hazard ratios for heart failure increase gradually from 1.01 in people with $\mathrm{TSH}$ of 4.5 to $6.9 \mathrm{mIU} / \mathrm{L}$ to 1.65 at levels between 7.0 of $9.9 \mathrm{mIU} / \mathrm{L}$ to 1.86 for levels between 10 to $19.9 \mathrm{mIU} / \mathrm{L} .32$ Similarly, the PreClS database study while evaluating multiple risk factors for cardiovascular risk factors concluded that moderate $\mathrm{SCH}$ (defined as 6.1-10 $\mu \mathrm{U} / \mathrm{mL}$ ) is one of the risks for all-cause mortality including coronary artery disease. ${ }^{33}$ Moreover, other studies have identified the association of $\mathrm{SCH}$ with coronary artery disease, especially in younger population groups. ${ }^{32-34}$ There are markers which were evaluated to determine underlying association of IHD with $\mathrm{SCH}$ as:

a: Carotid intima media thickness (CIMT): CIMT is a radiological surrogate marker of endothelial dysfunction and underlying ischemic heart disease. Dardano et al. and others have demonstrated markers like CIMT demonstrate deterioration in patients diagnosed to have $\mathrm{SCH}$ which improves once therapy normalises the TSH. ${ }^{12,35}$ 
b: Lipids: There are contrasts in evidence in terms of association between sub-optimal thyroid functioning and dyslipidemias.9,36 However, others have demonstrated lipid markers to get worsen with rise in TSH. ${ }^{12}$ Some like Herter-Aeberll et al. have shown only total cholesterol to be reduced with L-T4 therapy and did not show significant reduction in LDLc. 6

c: Metabolic syndrome: Recent data from Liu et al. demonstrate a clear association between components of metabolic syndrome and insulin resistance with $\mathrm{SCH} .{ }^{37}$ Hence, addressing $\mathrm{SCH}$ could be beneficial in reducing insulin resistance in metabolic factor.6,9

Pregnany: As mentioned above, the physiology in pregnancy varies from a non-pregnant subject which also includes changes in thyroid hormone levels due to circulating beta-hCG. Higher circulation of Beta-hCG in first trimester leads to hyper-stimulation of thyroid tissue, thus decreasing TSH levels. The upper cut-off of TSH in pregnancy is just $2.5 \mathrm{mlU} / \mathrm{L}$ in first trimester and 3.5 $\mathrm{mIU} / \mathrm{L}$ in last trimester. 38 Most data including ATA's adult treatment guidelines have recommended the use of thyroxin in patients with pregnancy associated $\mathrm{SCH}$ or identified adverse pregnancy outcomes. ${ }^{39-41}$

Autoimmunity: Vanderpump et al. in one of the Whickham survey follow-up studies highlighted that subjects with $\mathrm{SCH}$, who have positive anti-TPO antibodies, have a higher annual rate of progression to overt hypothyroidism.42 Walsh et al. have also demonstrated higher progression towards overt hypothyroidism in subjects with higher titers of TPOantibodies, $>2.5 \mathrm{mIU} / \mathrm{L} \mathrm{TSH}$ and female gender. 43 Other studies have identified autoimmunity based upon TPO and TSH antibody positivity and family history of Hashimoto's thyroiditis to be independent risk predictors of overt hypothyroidism. ${ }^{44}$ Moreover, the treatment with L-T4 in subjects with in Hashimoto's thyroiditis has been proven to stabilise the inflammation in thyroid disease. 45 However, it seems that the evidence of autoimmunity in patients with euthyroidism or $\mathrm{SCH}$ needs further trigger like genetic predispositions and environmental factors to trigger the inflammatory processes leading to thyroid gland destruction. ${ }^{46}$

Cognitive function: Current data do not show any strong association between $\mathrm{SCH}$ and cognitive decline. Forti et al. in his prospective trial spanning over fouryears did not observe an association between TSH levels and cognitive impairment or Alzheimer's disease, but did demonstrate an association with vascular dementia.47 Some anti-ageing clinics do recommend thyroxin use for even people with minimally deranged or normal thyroid function, but there is no hard evidence to support this association. 48 However, ongoing research about this association may be needed as the frequency of cognitive decline increases with overt hypothyroidism.

Hematological changes: There is a direct relationship between subclinical-hypothyroidism and anemia/ changes in hematological indices. ${ }^{49}$ Ravanbod et al. in a randomised control trial demonstrated that combined L-T4 treatment with iron therapy was found to be helpful in normalisation of iron deficiency anemia in patients having $\mathrm{SCH}$ in comparison to those treated with iron therapy alone.50 However, further research may be warranted to approve this finding.

GIT function: Evidence is available to suggest that certain upper $\mathrm{Gl}$ symptoms can be associated with patients having $\mathrm{SCH} .51$ However, the authors also concluded that the evidence is not strong as normalising TSH levels did not benefit their GI symptomology. More data, therefore, is needed to confirm such associations or otherwise.

Renal changes: Some researchers have shown subclinical-hypothyroid function to be associated with functional impairment of renal function. Kim et al. have demonstrated that thyroxine replacement attenuates the declining glomerular filtration rate in comparison to control population. ${ }^{52}$ Shin et al. have identified $\mathrm{SCH}$ as an independent predictor of renal outcome in patients with chronic kidney disease. 53

Reproductive system: Data associated with thyroid dysfunction in the shape of $\mathrm{SCH}$ is not associated with decline in reproductive function like reduced semen counts or infertility. ${ }^{54}$ Females, on the other hand, have shown a stronger link between $\mathrm{SCH}$ with subtle reproductive abnormalities like menstrual abnormalities to infertility. ${ }^{55}$ Moreover, studies have also documented an improvement in pregnancy outcomes in subjects after treatment of $\mathrm{SCH} .56$

Neuro-psychiatric issues: Some researchers have shown a link between $\mathrm{SCH}$ and reduction in quality of life (QoL) and improvement is observed after patient has achieved euthyroid status after therapy. ${ }^{57} \mathrm{~A}$ retrospective analysis by Hickiel et al. have shown that patients with treatment resistant depression have a higher prevalence of $\mathrm{SCH} .58$ In the light of highlighted association of depression/psychiatric disorders with $\mathrm{SCH}$, it may merit a trial of L-T4 therapy with appropriate monitoring.

Future prospects: While this review was focused on thyroid hormone parameters, it is felt that thyroid hormones in particular T3 affects all cells in the body by affecting the functioning of $\mathrm{Na}+/ \mathrm{K}+-$ ATPase pump. Suboptimal function or derangements encountered in function of this pump can lead to either pacing up of the synthetic processes or otherwise by its direct effect on basal metabolic rates. This concept thus also encompasses the effect on thyroid hormones beyond hypothalamic-pituitary-thyroidal axis to cellular and receptor levels where certain genetic changes like polymorphism or mutations can count towards the net TSH levels which could then affect various biochemical and clinical risks. ${ }^{59}$ Research in future with regard to 
thyroid function will thus possibly be including metabolism and energy consumption. $\mathrm{SCH}$, simply by slowing pace of $\mathrm{Na}+/ \mathrm{K}+-$ ATPase pump due to any genetic change, can lead to $\mathrm{SCH}$ causing predisposition to multiple metabolic risks leading to ischemic heart disease, obesity and decline in reproductive function. 59 Therefore, the authors believe that $\mathrm{SCH}$ is not simply related to HPA axis abnormality, rather could depict a secondary adjustments to cellular machinery defects like mutations or polymorphic changes along with role of autoimmunity, over the counter supplements, and nutritional habits.

\section{CONCLUSION}

Provided the known statistical variability resulting from subject's biological changes, the methodological limitations of available literature and evolving molecular level cellular research on thyroid hormones, it can be suggested that $\mathrm{SCH}$ will be taken into clinical practice as pathological entity. However, it remains fundamental here to interpret the TSH and associated thyroid hormone results in the broader clinical perspective of patient, the diet, and associated factors like autoimmunity, metabolic risks, and concerns of overtreatment. Treatment decision must be personalised and evidence-based. Figures 1 and 2 provide a general overview to segregate pathology from physiology where L-T4 therapy may benefit or harm. Fine tuning of TSH is difficult, but must be carried out to achieve physiological ranges by initiating minimal therapy and increase waiting time for clinical and biochemical response. Patients must be followed carefully for various risks mentioned in the review. Finally, it is felt that research is needed to improve our understanding of $\mathrm{SCH}$ by quality trials addressing not only harm-benefit perspective of LT-4 therapy, but molecular changes occurring at the cellular levels.

\section{REFERENCES}

1. Surks MI, Ortiz E, Daniels GH, Sawin CT, Col NF, Cobin RH, et al. Subclinical thyroid disease: scientific review and guidelines for diagnosis and management. JAMA 2004; 291: 228-38.

2. Hollowell JG, Staehling NW, Flanders WD, Hannon WH, Gunter EW, Spencer CA, et al. Serum TSH, T(4), and thyroid antibodies in the United States population (1988 to 1994): National health and nutrition examination survey (NHANES III). J Clin Endocrinol Metab 2002; 87:489-99.

3. Tunbridge WM, Evered DC, Hall R, Appleton D, Brewis M, Clark $\mathrm{F}$, et al. The spectrum of thyroid disease in a community: the Whickham survey. ClinEndocrinol (Oxf) 1977; 7:481-93.

4. Verburg FA, Kirchgässner $C$, Hebestreit $H$, Steigerwald $U$, Lentjes EG, Ergezinger $\mathrm{K}$, et al. Reference ranges for analytes of thyroid function in children. HormMetab Res 2011; 43:422-6.

5. Jonklaas J, Bianco AC, Bauer AJ, Burman KD, Cappola AR, Celi FS, et al. Guidelines for the treatment of hypothyroidism: Prepared by the American thyroid association task force on thyroid hormone replacement. Thyroid 2014; 24:1670-751.
6. Herter-Aeberli I, Cherkaoui M, El Ansari N, Rohner R, Stinca S, Chabaa $\mathrm{L}$, et al. lodine supplementation decreases hypercholesterolemia in iodine-deficient, overweight women: A randomized controlled trial. J Nutr 2015; 145:2067-75.

7. AlibazOner F, Yurdakul S, Oner E, Kubat Uzum A, Erguney M. Evaluation of the effect of L-thyroxin therapy on endothelial functions in patients with subclinicalhypothyroidism. Endocrine 2011; 40:280-4.

8. Kowalska I, Borawski J, Nikolajuk A, Budlewski T, Otziomek E, Górska $\mathrm{M}$, et al. Insulin sensitivity, plasma adiponectin and sICAM-1 concentrations in patients with subclinicalhypothyroidism: Response to levothyroxine therapy. Endocrine 2011; 40:95-101

9. Sathyapalan T, Manuchehri AM, Thatcher NJ, Rigby AS, Chapman T, Kilpatrick ES, et al. The effect of soy phytoestrogen supplementation on thyroid status and cardiovascular risk markers in patients with subclinicalhypothyroidism: a randomized, double-blind, crossover study. J Clin Endocrinol Metab 2011; 96:1442-9.

10. Shakoor SK, Aldibbiat A, Ingoe LE, Campbell SC, Sibal L, Shaw $\mathrm{J}$, et al. Endothelial progenitor cells in subclinicalhypothyroidism: the effect of thyroid hormone replacement therapy. J Clin Endocrinol Metab 2010; 95:319-22.

11. Adrees M, Gibney J, El-Saeity N, Boran G. Effects of 18 months of L-T4 replacement in women with subclinicalhypothyroidism. Clin Endocrinol (Oxf) 2009; 71:298-303

12. Mikhail GS, Alshammari SM, Alenezi MY, Mansour M, Khalil NA. Increased atherogenic low-density lipoprotein cholesterol in untreated subclinical-hypothyroidism. Endocr Pract 2008; 14:570-5.

13. Canaris GJ, Manowitz NR, Mayor G, Ridgway EC. The Coloradothyroid disease prevalence study. Arch Intern Med 2000; 160:526-34.

14. Garber JR, Cobin RH, Gharib H, Hennessey JV, Klein I, Mechanick $\mathrm{JI}$, et al. American association of clinical endocrinologists and American thyroid association taskforce on hypothyroidism in adults. Clinical practice guidelines for hypothyroidism in adults: co-sponsored by the American association of clinical endocrinologists and the American thyroid association. Endocr Pract 2012; 18:988-1028.

15. Radetti G, Maselli M, Buzi F, Corrias A, Mussa A, Cambiaso P, et al. The natural history of the normal/mild elevated TSH serum levels in children and adolescents with Hashimoto's thyroiditis and isolated hyperthyrotropinaemia: a 3-year followup? Clin Endocrinol (Oxf) 2012; 76:394-8.

16. Radetti G, Gottardi E, Bona G, Corrias A, Salardi S, Loche S. Study group for ghyroid diseases of the Italian society for pediatric endocrinology and diabetes (SIEDP/ISPED). The natural history of euthyroid Hashimoto's thyroiditis in children. J Pediatr 2006; 149:827-32.

17. Smit JW, Eustatia-Rutten CF, Corssmit EP, Pereira AM, Frölich M, Bleeker GB, et al. Reversible diastolic dysfunction after longterm exogenous subclinical hyperthyroidism: A randomized, placebo-controlled study. J Clin Endocrinol Metab 2005; 90:6041-7.

18. Auer J, Scheibner P, Mische T, Langsteger W, Eber O, Eber B. Subclinical-hyperthyroidism as a risk factor for atrial fibrillation. Am Heart J 2001; 142:838-42.

19. Casey BM, Dashe JS, Wells CE, Mclntire DD, Leveno KJ, Cunningham FG. Subclinical hyperthyroidism and pregnancy outcomes. Obstet Gynecol 2006; 107:337-41. 
20. Atkins P, Cohen SB, Phillips BJ. Drug therapy for hyperthyroidism in pregnancy: safety issues for mother and fetus. Drug Saf 2000; 23:229-44.

21. Chen JL, Chiu HW, Tseng YJ, Chu WC. Hyperthyroidism is characterized by both increased sympathetic and decreased vagal modulation of heart rate: evidence from spectral analysis of heart rate variability. Clin Endocrinol (Oxf) 2006; 64:611-6.

22. Ceresini G, Lauretani F, Maggio M, Ceda GP, Morganti S, Usberti $\mathrm{E}$, et al. Thyroid function abnormalities and cognitive impairment in elderly people: results of the Invecchiare in Chianti study. J Am Geriatr Soc 2009; 57:89-93.

23. Brennan MD, Powell C, Kaufman KR, Sun PC, Bahn RS, Nair KS. The impact of overt and subclinical-hyperthyroidism on skeletal muscle. Thyroid 2006; 16:375-80.

24. De Rosa G, Testa A, Giacomini D, Carrozza C, Astazi P, Caradonna P. Prospective study of bone loss in pre- and postmenopausal women on L-thyroxine therapy for non-toxic goitre. Clin Endocrinol (Oxf) 1997; 47:529-35.

25. Belaya ZE, Melnichenko GA, Rozhinskaya LY, Fadeev VV, Alekseeva TM, Dorofeeva OK, et al. Subclinical-hyperthyroidism of variable etiology and its influence on bone in postmenopausal women. Hormones (Athens) 2007; 6:62-70.

26. Schneider R, Reiners $C$. The effect of levothyroxine therapy on bone mineral density: a systematic review of the literature. Exp Clin Endocrinol Diabetes 2003; 111:455-70.

27. Greenspan SL, Greenspan FS, Resnick NM, Block JE, Friedlander AL, Genant HK. Skeletal integrity in premenopausal and postmenopausal women receiving long-term L-thyroxine therapy. Am J Med 1991; 91:5-14.

28. Lakatos P. Thyroid hormones: beneficial or deleterious for bone? Calcif Tissue Int 2003; 73:205-9.

29. Kasperlik-Zaluska A, Czarnocka B, Czech W. High prevalence of thyroid autoimmunity in idiopathic Addison's disease. Autoimmunity 1994; 18:213-6.

30. Taylor PN, Iqbal A, Minassian C, Sayers A, Draman MS, Greenwood R, et al. Falling threshold for treatment of borderline elevated thyrotropin levels - balancing benefits and risks: evidence from a large community-based study. JAMA Intern Med 2014; 174:32-9.

31. Razvi S, Weaver JU, Vanderpump MP, Pearce SH. The incidence of ischemic heart disease and mortality in people with subclinical hypothyroidism: Re-analysis of the Whickham Survey cohort. J Clin Endocrinol Metab 2010; 95:1734-40.

32. Gencer B, Collet TH, Virgini V, Bauer DC, Gussekloo J, Cappola AR, et al. Thyroid studies collaboration. Subclinical thyroid dysfunction and the risk of heart failure events: an individual participant data analysis from 6 prospective cohorts. Circulation 2012; 126:1040-9.

33. McQuade C, Skugor M, Brennan DM, Hoar B, Stevenson C, Hoogwerf BJ. Hypothyroidism and moderate subclinical hypothyroidism are associated with increased all-cause mortality independent of coronary heart disease risk factors: a PreCIS database study. Thyroid 2011; 21:837-43.

34. Ochs N, Auer R, Bauer DC, Nanchen D, Gussekloo J, Cornuz J, et al. Meta-analysis: subclinical thyroid dysfunction and the risk for coronary heart disease and mortality. Ann Intern Med 2008; 148:832-45.

35. DardanoA, Monzani F. Thyroid function and carotid artery intima-media thickness. Circ J 2007; 71:993.
36. Iqbal A, Jorde R, Figenschau Y. Serum lipid levels in relation to serum thyroid-stimulating hormone and the effect of thyroxine treatment on serum lipid levels in subjects with subclinical hypothyroidism: the Tromsø study. J Intern Med 2006; 260: 53-61.

37. Liu C, Scherbaum WA, Schott M, Schinner S. Subclinicalhypothyroidism and the prevalence of the metabolic syndrome. Horm Metab Res 2011; 43:417-21.

38. Vyakaranam S, Vanaparthy S, Nori S, Palarapu S, Bhongir AV. Study of insulin resistance in subclinical-hypothyroidism. Int $J$ Health Sci Res 2014; 4:147-53.

39. Garber JR, Cobin RH, Gharib H, Hennessey JV, Klein I, Mechanick $\mathrm{Jl}$, et al. American association of clinical endocrinologists and American thyroid association taskforce on hypothyroidism in adults. Clinical practice guidelines for hypothyroidism in adults: co-sponsored by the American association of clinical endocrinologists and the American thyroid association. Thyroid 2012; 22:1200-35.

40. Bocos-Terraz JP, Izquierdo-Alvarez S, Bancalero-Flores JL, Alvarez-Lahuerta R, Aznar-Sauca A, Real-López E, et al. Thyroid hormones according to gestational age in pregnant Spanish women. BMC Res Notes 2009; 2:237

41. Chen LM, Du WJ, Dai J, Zhang Q, Si GX, Yang $H$, et al. Effects of subclinical hypothyroidism on maternal and perinatal outcomes during pregnancy: A single-center cohort study of a Chinese population. PLoS One 2014; 9:e109364.

42. Vanderpump MP, Tunbridge WM, French JM, Appleton D, Bates D, Clark F, et al. The incidence of thyroid disorders in the community: a twenty-year follow-up of the Whickham survey. Clin Endocrinol (Oxf) 1995; 43:55-68.

43. Walsh JP, Bremner AP, Feddema P, Leedman PJ, Brown SJ, O'Leary P. Thyrotropin and thyroid antibodies as predictors of hypothyroidism: A 13-year, longitudinal study of a communitybasedcohort using current immunoassay techniques. J Clin Endocrinol Metab 2010; 95:1095-104.

44. Strieder TG, Tijssen JG, Wenzel BE, Endert E, Wiersinga WM. Prediction of progression to overt hypothyroidism or hyperthyroidism in female relatives of patients with autoimmune thyroid disease using the Thyroid Events Amsterdam (THEA) score. Arch Intern Med 2008; 168:1657-63.

45. Korzeniowska K, Jarosz-Chobot P, Szypowska A, Ramotowska A, Fendler W, Kalina-Faska B, et al. L-thyroxine stabilizes autoimmune inflammatory process in euthyroidnongoitrous children with Hashimoto's thyroiditis and type 1 diabetes mellitus. J Clin Res Pediatr Endocrinol 2013; 5:240-4.

46. Balázs $C$. The role of hereditary and environmental factors in autoimmune thyroid diseases. Orv Hetil 2012; 153:1013-22.

47. Forti P, Olivelli V, Rietti E, Maltoni B, Pirazzoli G, Gatti R, et al. Serum thyroid-stimulating hormone as a predictor of cognitive impairment in an elderly cohort. Gerontology 2012; 58:41-9.

48. Hogervorst E, Huppert F, Matthews FE, Brayne C. Thyroid function and cognitive decline in the MRC Cognitive Function and Ageing Study. Psychoneuroendocrinology 2008; 33:1013-22.

49. Bashir H, Bhat MH, Farooq R, Majid S, Shoib S, Hamid R, et al. Comparison of hematological parameters in untreated and treated subclinical hypothyroidism and primary hypothyroidism patients. Med J Islam Repub Iran 2012; 26:172-8.

50. Ravanbod M, Asadipooya K, Kalantarhormozi M, Nabipour I, Omrani GR. Treatment of iron-deficiency anemia in patients with subclinical hypothyroidism. Am J Med 2013; 126:420-4. 
51. Canpolat AG, Kav T, Sivri B, Yildiz BO. Effects of L-thyroxine on gastric motility and ghrelin in subclinicalhypothyroidism: a prospective study. J Clin Endocrinol Metab 2013; 98:E1775-9.

52. Kim EO, Lee IS, Choi YA, Lee SJ, Chang YK, Yoon HE, et al. Unresolved subclinical hypothyroidism is independently associated with progression of chronic kidney disease. Int $\mathrm{J}$ Med Sci 2013; 11:52-9.

53. Shin DH, Lee MJ, Lee HS, Oh HJ, Ko KI, Kim CH, et al. Thyroid hormone replacement therapy attenuates the decline of renal function in chronic kidney disease patients with subclinical hypothyroidism. Thyroid 2013; 23:654-61.

54. Poppe K, Glinoer D, Tournaye H, Maniewski U, Haentjens P, Velkeniers B. Is systematic screening for thyroid disorders indicated in subfertile men? Eur J Endocrinol 2006; 154: 363-6.

55. Pei YJ, Wang AM, Zhao Y, Yan L, Li M, White RE, et al. Studies of cardiovascular risk factors in polycystic ovary syndrome patients combined with subclinical hypothyroidism. Gynecol Endocrinol 2014; 30:553-6.

56. Yoshioka W, Amino N, Ide A, Kang S, Kudo T, Nishihara E, et al. Thyroxine treatment may be useful for subclinical hypothyroidism in patients with female infertility. Endocr $J$ 2015; 62:87-92.

57. Gulseren S, Gulseren L, Hekimsoy Z, Cetinay P, Ozen C, Tokatlioglu B. Depression, anxiety, health-related quality of life, and disability in patients with overt and subclinical thyroid dysfunction. Arch Med Res 2006; 37:133-9.

58. Hickie I, Bennett B, Mitchell P, Wilhelm K, Orlay W. Clinical and subclinical-hypothyroidism in patients with chronic and treatment-resistant depression. Aust N Z J Psychiatry 1996; 30:246-52.

59. Ayers S, Switnicki MP, Angajala A, Lammel J, Arumanayagam AS, Webb P. Genome-wide binding patterns of thyroid hormone receptor beta. PLoS One 2014; 9:e81186.

.... $\hat{\imath} \ldots$. 